\title{
Prospek Bisnis Briket Daun Kering dalam Kegiatan Pendampingan dan Pemberdayaan Masyarakat Surabaya Menuju Ekonomi Sirkular
}

\author{
Hadi Santosa $^{1}$, Yuliati $^{2 *}$, Suratno Laurentius ${ }^{3}$, Setiyadi $^{3}$ \\ ${ }^{1}$ Jurusan Teknik Industri, ${ }^{2}$ Jurusan Teknik Elektro, ${ }^{3}$ Jurusan Teknik Kimia \\ Fakultas Teknik Universitas Katolik Widya Mandala Surabaya \\ Jl. Kalisari Selatan No.1 Pakuwon City Mulyorejo Surabaya 60112 Jawa Timur \\ *E-mail : yuliati@ukwms.ac.id \\ DOI: https://doi.org/10.21107/pangabdhi.v7i2.11604 \\ Naskah diterima 8 Agustus 2021, Revisi 27 Agustus 2021, Terbit 29 Oktober 2021
}

\begin{abstract}
Waste processing activities through the $3 R$ program (reduce, reuse and recycle) must be accompanied by reducing the volume/amount of waste itself. One way is to process waste starting from the source, among others, from dry leaf waste around our home environment. Community assistance activities in the use of dry leaves in the manufacture of charcoal briquettes as an alternative energy for environmental facilitators and Surabaya residents have been successfully carried out. The response of the residents was very positive and very enthusiastic in participating in this activity. The stages of implementing activities through workshops, training and mentoring are carried out in the form of lectures, questions and answers and direct practice in making briquettes. The results obtained in this community service are the formation of three superior briquette villages, namely Babat Jerawat, Tembok Gede and Ondomohen. The residents independently have succeeded in designing and making their own briquette printing equipment by utilizing used goods around them and making charcoal briquettes from dry leaves or burnt coconut shell charcoal and even has succeeded in marketing it even though it is still within the scope of the closest neighbors. Education about business prospects and marketing strategies was also given during training in empowering urban communities and responding to existing business opportunities and prospects so that they had a circular economy impact for community members to improve family welfare.
\end{abstract}

Key Words : briquettes, business, prospects, dry leaves, circular economy, opportunities

\section{PENDAHULUAN}

Total produksi sampah nasional pada tahun 2020 telah mencapai 67,8 juta ton. Hal ini berarti bahwa dari 270 juta penduduk Indonesia, estimasi sampah yang dihasilkan sekitar 185.753 ton sampah per harinya atau sekitar 0,68 kilogram sampah per hari per orang. Sampah yang menumpuk dan menggunung di beberapa Tempat Pembuangan Akhir (TPA) di beberapa wilayah Indonesia, baik dalam bentuk organik maupun non-organik dapat menjadi sebuah masalah besar. Apabila sampah tidak tertangani dengan baik, tentunya hal ini berdampak pada pencemaran dan kerusakan lingkungan karena tumpukan sampah akan dapat memproduksi gas metana dan bahkan dapat membahayakan jiwa manusia.

Kendala lain dalam pengelolaan sampah adalah masih rendahnya rata-rata kapasitas pengelolaan sampah dibawah $50 \%$. Daya serap kegiatan daur ulang dan bank sampah di masyarakat masih rendah, di mana masih berkisar 11\%. Pada umumnya dari sekitar 514 kabupaten/kota yang tersebar di Indonesia masih digunakannya pola lama / pola linier dengan cara kumpul-angkut-buang (Kementerian Lingkungan Hidup dan Kehutanan, 2020). Sementara itu volume sampah di Surabaya mencapai \pm 1300 1400 ton/hari dan hanya memiliki satu tempat pembuangan sampah akhir (TPA) di Benowo dengan luas $\pm 37,4 \mathrm{Ha}$ (Kompas, 2019).

Fenomena yang terjadi telah menumbuhkan ide inovatif yaitu bagaimana sampah dapat dikelola dan dimanfaatkan kembali bahkan dapat menjadi berkah bagi manusia, ramah lingkungan dan bahkan mampu meningkatkan tingkat pergerakan ekonomi di lingkungan masyarakat sehingga terbangun kegiatan ekonomi sirkular (circular economy). Potensi pengelolaan sampah dengan konsep 3R (reduce, reuse, recycle) merupakan upaya yang sangat efektif dalam mengurangi jumlah sampah yang masuk maupun mengendalikan volume timbunan sampah yang menggunung di TPA (Arlini et al., 2017). Sampah dapat dikelola dan diolah dengan baik 
dengan konsep 3R yang dilakukan secara komprehensif dan terintegrasi dari berbagai aspek baik aspek sosial, lingkungan, teknis sampai bisnis dan ekonomi. Oleh sebab itu, saat ini sudah semestinya berbagai elemen warga masyarakat mengadopsi konsep terkini yaitu ekonomi sirkular (circular economy) dengan memanfaatkan nilai ekonomi sampah secara maksimal agar sampah dapat mendatangkan berkah dan manfaat bagi kehidupan manusia.

Upaya tata kelola sampah masih harus terus dilakukan, diperbaiki dan dikembangkan mulai dari mendaur ulang sampah menjadi sumber energi baru terbarukan, pembangkit listrik, daur ulang menjadi produk bernilai ekonomis, hingga kampanye nasional diet plastic (Pasande et al., 2021). Dalam hal ini sampah dapat beralih fungsi dari hanya sebagai produk buangan menjadi bahan baku yang mampu mengekskalasi nilai ekonomi dalam pergerakan ekonomi masyarakat. Potensi ini didukung dengan melimpahnya sumber produksi sampah karena sebanyak 60 persen produksi sampah nasional yang berasal dari limbah rumah tangga.

Pengelolaan sampah dari, oleh dan untuk masyarakat adalah sebagai upaya penanganan, pengendalian sampah seyogyanya melibatkan partisipatif aktif dari masyarakat. Berbagai upaya dalam memanfaatkan kembali sampah organik maupun non-organik berbasis kerakyatan menjadi produk produk yang bernilai ekonomis telah lakukan diantara lain: pengolahan sampah organik menjadi pupuk kompos, pembuatan eco-brick, limbah kotoran hewan dalam bentuk biogas, maupun sampah organik daun /ranting kering menjadi arang briket (bio-briket) (Sari, 2018; Suryani et al., 2019).

Dinas Kebersihan dan Ruang Terbuka Hijau (DKRTH) Kota Surabaya menjalin kerjasama dengan tim pengabdian masyarakat Teknologi Tepat Guna Arang Briket Fakultas Teknik Universitas Katolik Widya Mandala Surabaya sebagai narasumber dan instruktur dalam program dan kegiatan workshop, pelatihan, konsultasi dan pendampingan masyarakat perkotaan Surabaya dalam pengelolaan sampah organik menjadi sumber energi baru dan terbarukan bio-briket. Kegiatan pembinaan dan pemberdayaan masyarakat dalam bentuk workshop/pelatihan oleh DKRTH telah dilakukan tentang sosialisasi pengelolaan sampah, program pengurangan sampah melalui $3 \mathrm{R}$ (reduce, reuse dan recycle) nya. Kegiatan ini bertujuan untuk pengelolaan dan pengolahan sampah yang bersumber dari sekitar lingkungan/ rumah warga agar dapat dikendalikan, dikurangi, dan dimanfaatkan serta didaur ulang kembali sehingga tidak menumpuk di TPA. Pemkot Surabaya saat ini melalui DKRTH telah memiliki 36 rumah kompos dan 3 rumah pusat daur ulang dan akan terus dikembangkan ditahun yang akan datang. Namun, masih diperlukan diversifikasi dalam pengendalian dan pengolahan sampah serta harus diimplementasikan dengan baik, efektif dan efisien.

\section{METODE}

Metode pelaksanaan dan strategi yang telah dilakukan tim pengabdian kepada masyarakat dalam kegiatan workshop, penyuluhan, pelatihan dan pendampingan serta edukasi tentang analisa ekonomi, strategi pemasaran dan prospek bisnis arang briket dari daun kering ini adalah :

a) Kolaborasi dan kerjasama yang baik antara pihak perguruan tinggi dalam hal ini Fakultas Teknik Universitas Katolik Widya Mandala Surabaya (FT-UKWMS) dalam hal ini adalah tim Teknologi Tepat Guna pengabdian masyarakat dari ketiga jurusan yaitu teknik industri, teknik elektro dan teknik kimia dengan Dinas Kebersihan dan Ruang Terbuka Hijau (DKRTH) Pemerintah Kota Surabaya.

b) Pembuatan alat cetak briket dan kompor briket sebagai alat peraga dalam seluruh rangkaian kegiatan pendampingan kepada masyarakat seperti ditunjukkan pada Gambar 1.

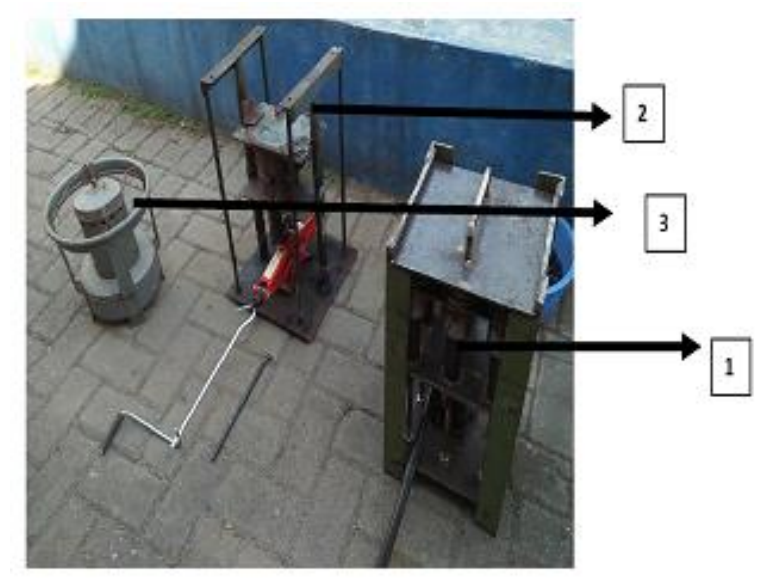

Gambar 1. Alat Cetak dan Kompor Briket Keterangan :

1. Alat pencetak model tablet yang terdiri dari 8 buah lubang cetakan briket, masing masing berukuran diameter $5 \mathrm{~cm}$ dan tinggi $8 \mathrm{~cm}$. 
2. Alat pencetak model tabung yang terdiri dari 1 lubang cetakan tabung berukuran diameter $15 \mathrm{~cm}$ dengan ketinggian $8 \mathrm{~cm}$.

3. Kompor Briket

c) Penyusunan modul dan video pelatihan sebagai media pembelajaran sehingga warga masyarakat dapat dengan mudah memahami langkah langkah/cara dalam pembuatan arang briket dari sampah organik. Link url video pelatihan adalah https://www.youtube.com/watch? $\mathrm{v}=\mathrm{mKVZGmp}$ ayPs . Pada video ini diberikan gambaran bahan bahan yang dibutuhkan dan setiap langkah proses pembuatan arang briket dari sampah daun kering.

d) Kegiatan workshop, pelatihan, penyuluhan dan pendampingan dilaksanakan dalam kurun waktu Maret 2019 - Maret 2020. Setidaknya kegiatan abdimas dalam bentuk "road show" ini terdapat 11 titik lokasi di tingkat RT/RW/Kelurahan di wilayah Kota Surabaya mulai dari Surabaya pusat, barat, timur , utara dan selatan, antara lain Babat Jerawat, Gundih, Kedung Klinter, Kemayoran, Morokrembangan, Ondomohen, Pacar keling, Penjaringansari, Tanah Kalikedinding, dan Wiyung. Kegiatan workshop fasilitator lingkungan Surabaya yang dihadiri tidak kurang dari 200 faskel dapat ditunjukkan pada Gambar 2.

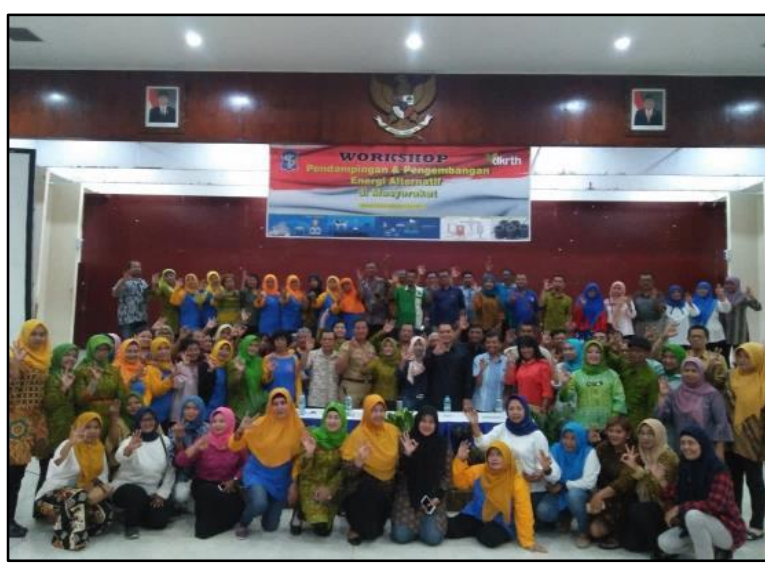

Gambar 2. Peserta Kegiatan Workshop

Fasilitator Lingkungan Surabaya

Kegiatan pengabdian masyarakat diawali dengan workshop bagi para fasilitator lingkungan (faskel) Surabaya. Dari para kader lingkungan ini diharapkan dapat menjadi penggerak dan motivator warga dalam berkreasi dan berinovasi dalam pemanfaatan sampah organik daun menjadi arang briket. Keuntungan pembuatan arang briket dibanding pembuatan kompos maupun biogas adalah proses pembuatannya lebih cepat dan lebih mudah serta bahan baku yang melimpah. Pengolahan sampah harus disertai dengan mengurangi volume/jumlah sampah itu sendiri dan salah satu cara adalah dengan mengolah sampah dimulai dari sumbernya antara lain dari sampah daun kering di sekitar lingkungan rumah kita. Khususnya di perkotaan, luas lahan yang semakin sempit berakibat masyarakat kesulitan mencari lahan pembuangan sampah,

Luaran dari kegiatan workshop ini terdapat beberapa wilayah yang tertarik dan berkomitmen untuk melakukan pengelolaan dan pembuatan arang briket daun kering. Kegiatan berlanjut dalam bentuk pendampingan ke berbagai wilayah yang tersebar di 11 titik wilayah mulai dari Surabaya pusat, barat, timur, utara, selatan dalam pemanfaatan energi baru terbarukan arang briket dari sampah organik melalui pemberdayaan masyarakat telah dilaksanakan dan mendapatkan respon positif dari warga masyarakat. Kegiatan ini juga merupakan bentuk kerjasama antara pihak Dinas Kebersihan dan Ruang Terbuka Hijau (DKRTH) Pemerintah Kota Surabaya dengan institusi perguruan tinggi dalam upaya memberikan edukasi kepada warga dalam pemanfaatan sampah organik daun kering menjadi arang briket. Hasil pendampingan ini muncul beberapa inovasi dari warga dalam bentuk desain alat pencetak arang briket, variasi komposisi bahan pembuatan briket dan bahkan beberapa warga juga telah berhasil memasarkan briket daun kering walaupun masih terbatas dalam lingkup penjualannya terbatas pada lingkungan tetangga sekitar saja.

Sampah organik dalam kegiatan pendampingan masyarakat ini terdiri dari daun kering, sekam padi, ranting, maupun serbuk gergaji yang tersedia di sekitar pemukiman warga sebagai bahan pembuatan bio-briket. Briket merupakan suatu bahan bakar padat dan berasal dari sisa-sisa bahan organik yang telah mengalami pemampatan dengan daya tekan tertentu. Briket merupakan sumber energi alternatif yang potensial dan dapat diandalkan untuk rumah tangga. (Yudhita \& Utami, 2015). Pada prinsipnya, proses pembuatan arang briket dari sampah organik terdiri dari proses pengarangan, pengayakan, pencampuran bahan, pencetakan dan pengeringan. (Purnama, Chumaidi \& Saleh, 2012)

\section{HASIL PEMBAHASAN}

Kegiatan pemberdayaan masyarakat perkotaan Surabaya dalam mengelola dan mengolah sampah menjadi energi baru terbarukan arang briket ini merupakan kolaborasi antara pihak perguruan 
tinggi dan DKRTH pemerintah Kota Surabaya. Dari analisa situasi dan identifikasi kebutuhan, maka kegiatan ini diharapkan dapat menambah pengetahuan dan ketrampilan masyarakat dalam pengelolaan lingkungan dan pengolahan sampah organik sebagai sumber energi alternatif terbarukan yang berkelanjutan dan memiliki nilai ekonomi dan bisnis yang lebih prospektif berbasis smart environment menuju ekonomi sirkular. Sampah organik dalam kegiatan pendampingan masyarakat ini terdiri dari daun kering, sekam padi, ranting, maupun serbuk gergaji yang tersedia di sekitar pemukiman warga, serta tepung tapioka dan air sebagai bahan perekatnya.

\section{Briket Sebagai Sumber Energi Alternatif}

Kegiatan workshop pendampingan dan pengembangan energi alternatif di masyarakat yang diselenggarakan oleh DKRTH Pemkot Surabaya dengan narasumber dari tim teknologi tepat guna Fakultas Teknik Universitas Katolik Widya Mandala Surabaya (UKWMS), maka pada tanggal 23 April 2019 dilaksanakan kegiatan workshop pemanfaatan briket dari sampah organik yang dihadiri oleh \pm 125 para fasilitator kelurahan (FASKEL) se-Kota Surabaya dengan penuh antusias (Gambar 3). Hasil kegiatan workshop ini adalah para fasilitator lingkungan memberikan respons positif akan hasil pelaksanaan kegiatan ini dan menghimbau untuk dilanjutkan dalam bentuk pelatihan, penyuluhan dan pendampingan kepada warga masyarakat dalam lingkup RW atau kelurahan yang membutuhkan pelatihan lanjutan. Setidaknya terdapat 11 wilayah yang mengajukan untuk diadakan pelatihan lanjutan.

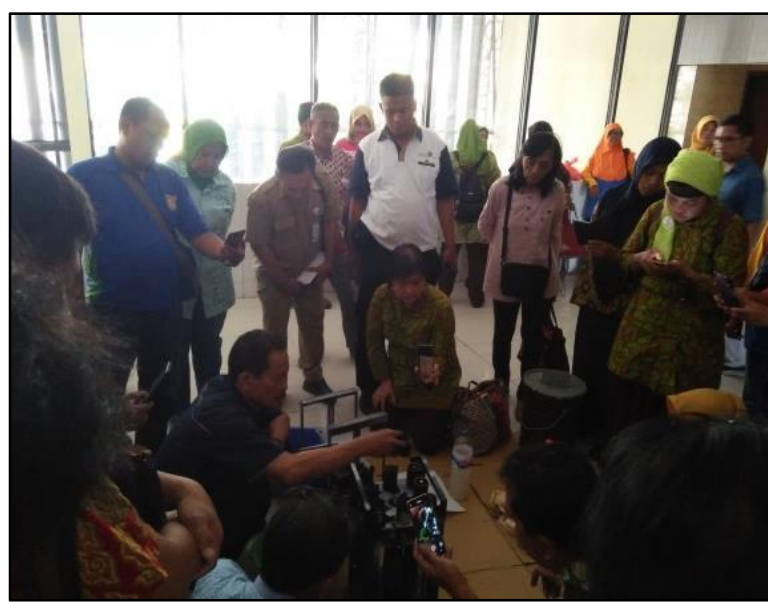

Gambar 3.

Pelatihan Praktek Pembuatan Arang Briket Sampah Organik

\section{Inovasi Alat Cetak Briket}

Seperti dalam pemaparan sebelumnya, setidaknya 11 lokasi di beberapa wilayah di Surabaya yang telah melalui proses pelatihan dan pendampingan seperti ditunjukkan pada gambar 6 wilayah yaitu Gundih, Babat Jerawat, Ondomohen, Morokrembangan dan Tembok Gede masing masing telah berhasil berinovasi dalam pembuatan arang briket sampah organik dalam bentuk alat cetak, komposisi bahan, maupun pengemasan arang briketnya. Warga Babat Jerawat, Ondomohen dan Tembok Gede telah berinovasi membuat alat cetak briket dengan memanfaatkan barang bekas dan bahkan arang briketnya telah berhasil mendapatkan pesanan dari Gresik seperti ditunjukkan pada Gambar 4. Walaupun masih dalam skala kecil. Hal ini menunjukkan bahwa arang briket sampah organik ini cukup prospektif dalam bisnis sehingga mampu tercipta ekonomi berkelanjutan dengan memanfaatkan sampah organik (Gambar 5).

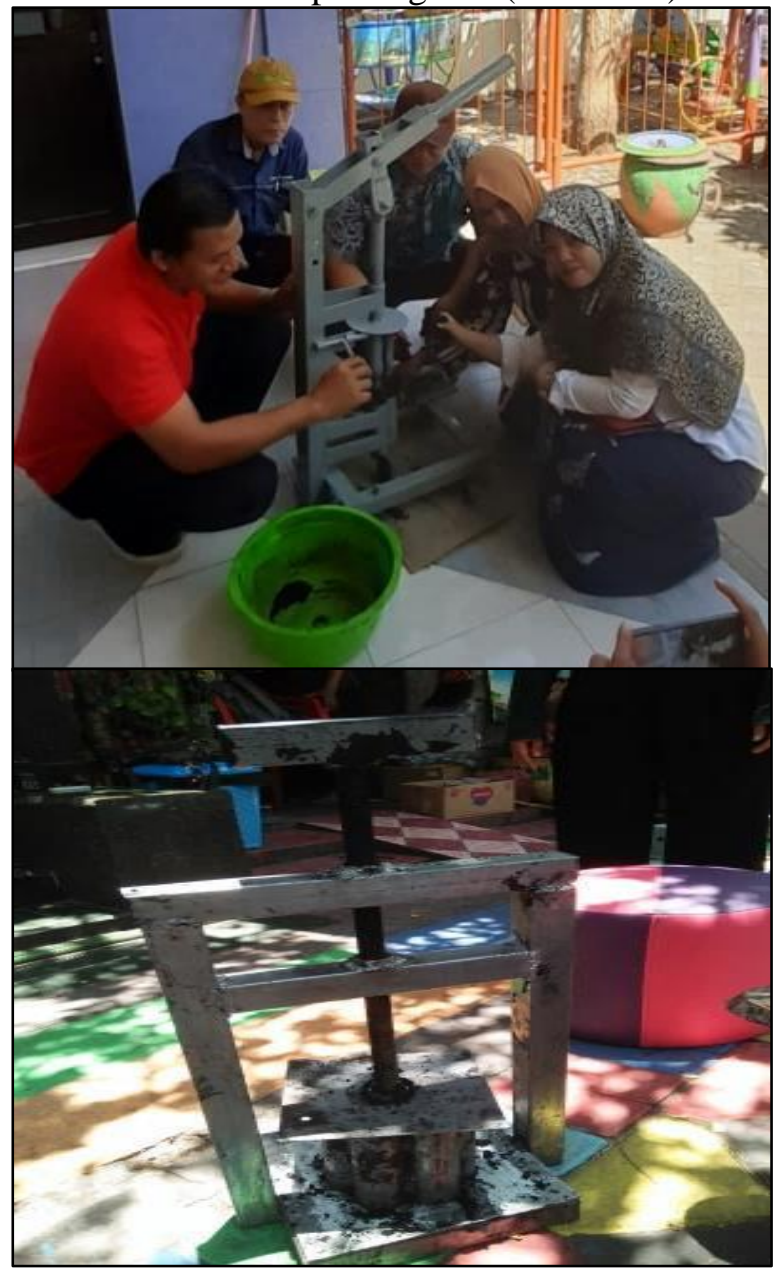

Gambar 4.

Inovasi Alat Cetak Briket Produk Masyarakat 


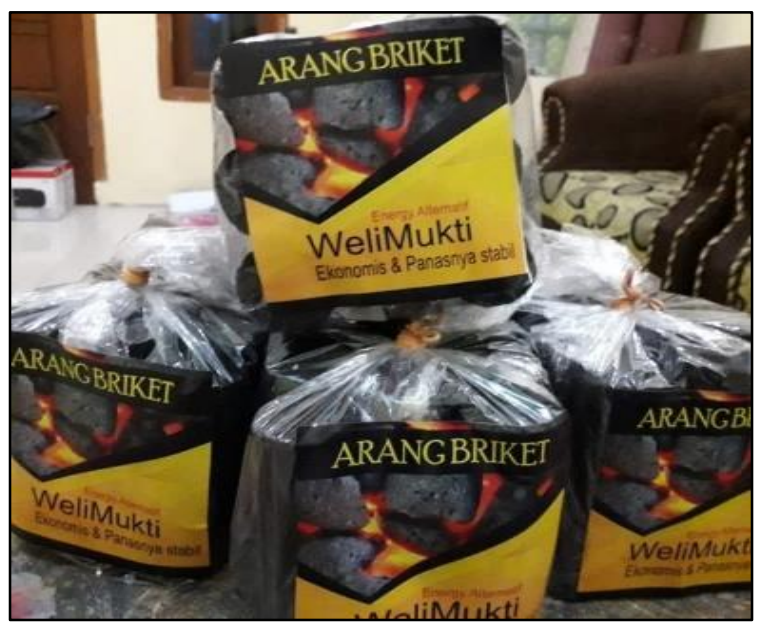

Gambar 5. Hasil Produksi Arang Briket

Tabel 1. Simulasi Perhitungan Harga Pokok Produksi (HPP) Arang Briket Daun Kering

\begin{tabular}{|l|c|c|c|}
\hline $\begin{array}{c}\text { Uraian } \\
\text { Biaya }\end{array}$ & $\begin{array}{c}\text { Biaya/hr } \\
(\mathrm{Rp})\end{array}$ & Biaya/bln (Rp) & Biaya/thn (Rp) \\
\hline Biaya Tetap: & & & \\
\hline $\begin{array}{l}\text { Tenaga Kerja } \\
\text { Langsung. }\end{array}$ & 50,000 & $1,250,000$ & $15,000,000$ \\
\hline Biaya Sewa. & 0 & 0 & 0 \\
\hline Biaya Alat. & 0 & 0 & $3,000,000$ \\
\hline Depresiasi Alat. & 0 & 0 & 280,000 \\
\hline $\begin{array}{l}\text { Biaya Lain - } \\
\text { Lain. }\end{array}$ & 2,500 & 62,500 & 750,000 \\
\hline Biaya Variabel: & & & \\
\hline $\begin{array}{l}\text { Sampah } \\
\text { Daun/100 kg. }\end{array}$ & 10,000 & 250,000 & $3,000,000$ \\
\hline $\begin{array}{l}\text { Tepung } \\
\text { Tapioka. }\end{array}$ & 50,000 & $1,250,000$ & $15,000,000$ \\
\hline Air. & 3,000 & 75,000 & 900,000 \\
\hline $\begin{array}{l}\text { Bensin/ minyak } \\
\text { tanah }\end{array}$ & 9,000 & 225,000 & $2,700,000$ \\
\hline Packaging & 20,000 & 500,000 & $6,000,000$ \\
\hline $\begin{array}{l}\text { Jumlah Harga } \\
\text { Pokok Produksi }\end{array}$ & & & $46,630,000$ \\
\hline
\end{tabular}

Tabel 2. Hasil Perhitungan ekonomi

\begin{tabular}{|c|l|c|}
\hline No & \multicolumn{1}{|c|}{ Deskripsi } & Jumlah (Rp) \\
\hline 1 & $\begin{array}{l}\text { Pendapatan bersih (15,000kg, @ } \\
\text { Rp 4,500) }\end{array}$ & $67,500,000$ \\
\hline 2 & Harga Pokok Produksi. & $46,630,000$ \\
\hline 3 & Laba Kotor dari Pendapatan. & $20,870,000$ \\
\hline 4 & $\begin{array}{l}\text { Biaya Pemasaran (Rp } \\
100,000 / \text { bulan). }\end{array}$ & $1,200,000$ \\
\hline 5 & Laba Bersih sebelum Pajak. & $19,670,000$ \\
\hline 6 & Pajak 10\%. & $1,967,000$ \\
\hline 7 & $\begin{array}{l}\text { Laba Bersih Setelah Pajak } \\
\text { (pertahun untuk 15,000 kg). }\end{array}$ & $17,703,000$ \\
\hline 8 & Laba Bersih per Kilogram. & 1,180 \\
\hline 9 & Laba per kilogram per bulan & $1,475,250$ \\
\hline 10 & Laba per hari & 59,010 \\
\hline
\end{tabular}

Berdasarkan hasil simulasi perhitungan ekonomi di atas, maka pemanfaatan sampah organik menjadi energi baru terbarukan dengan upaya pengembangan yang selalu berkelanjutan baik dari sisi teknologi berbasis kerakyatan maupun mutu arang briket merupakan suatu peluang dan memiliki prospek bisnis dan diharapkan akan mampu mendorong ekonomi sirkular bagi peningkatan kesejahteraan keluarga. Warga Ondomohen telah memasarkan arang briket dari sampah organik dengan harga $\mathrm{Rp}$. $25.000,-/ \mathrm{kg}$ dan warga tembok Gede juga telah memasarkan arang briketnya dengan harga $\mathrm{Rp}$ 20.000 untuk setiap 10 butir arang dalam kemasannya. Apabila kegiatan ekonomi dengan membuat arang briket dari sampah organik dengan teknologi berbasis kerakyatan ini dapat berlanjut secara kontinyu, maka tentunya akan mampu tercipta kegiatan masyarakat dalam pemanfaatan energi alternatif dengan berbasis smart environment sehingga akan tercipta ekonomi sirkular yang berkelanjutan.

\section{KESIMPULAN}

Kesimpulan dari hasil kegiatan pengabdian kepada masyarakat melalui pemberdayaan masyarakat dalam prospek bisnis briket arang sampah organik daun kering menuju ekonomi sirkular adalah adanya peningkatan pengetahuan dan ketrampilan masyarakat dalam pengelolaan dan pemanfaatan sampah organik menjadi arang briket yang memiliki nilai ekonomis telah terbentuk dalam kegiatan pendampingan energi baru terbarukan ini. Perbaikan, pengembangan dan upaya yang berkelanjutan dalam pemanfaatan sampah organik menjadi energi baru terbarukan diperlukan dalam rancang alat cetak briket dan juga mutu hasil briket sampah organik dengan prinsip 3R berbasis teknologi kerakyatan serta analisa eknomi dan prospek bisnis arang briket dari sampah organik ini diharapkan akan mampu mendorong ekonomi sirkular bagi peningkatan kesejahteraan keluarga.

\section{UCAPAN TERIMA KASIH}

Ucapan terimakasih kami sampaikan kepada pihak Dinas Kebersihan dan Ruang Terbuka Hijau (DKRTH) Pemerintah Kota Surabaya atas kesempatan dan menfasilitasi kegiatan mulai dari workshop bagi 100 fasilitator lingkungan se-Kota Surabaya, pelatihan penyuluhan dan pendampingan di 11 titik wilayah Kota Surabaya. 


\section{DAFTAR PUSTAKA}

Arlini, D.R., Jenny C., Diyah KR. (2017). Potensi Reduce, Reuse, Recycle (3R) Sampah pada Bank Sampah "Bank Junk for Surabaya Clean (BJSC), Jukung Jurnal Teknik Lingkungan 3(1) : 1-11.

Martala, S., Lestari, S.U \& Raudhah, A . (2018), Peningkatan Ketrampilan Mahasiswa dalam Pengelolaan Sampah Organik Untuk Mewujudkan Green Campus di Universitas Lancang Kuning. Dinamisia- Jurnal Pengabdian Kepada Masyarakat Vol. 2, No. 2 Desember 2018, Hal. 193-196.

Lely Suryani., Ariswan Usman Aje., Kristianus J. Tute. (2019). PKM Pelatihan Kelompok Anak Cinta Lingkungan kabupaten Ende dalam pengelolaan Lombah Organik dan Anorganik Berbasis 3R untuk Mengekskalasi Nilai Eknomis barang Sebagai Bekal Wirausaha Mandiri. Dinamisia-Jurnal Pengabdian Kepada Masyarakat Vol. 3, No. 2 Desember 2019, Hal. 244-251.

Purnama Pasande., Ezra Tari. (2021). Daur Ulang Sampah di Desa Paisbuloli Sulawesi Tenggara. Dinamisia-Jurnal Pengabdian Kepada Masyarakat Vol. 5, No. 1 Februari 2021, Hal. 147-153.

Yuliati., Hadi Santosa, Suratno Lourentius., Setyadi. (2020). Pelatihan Pemanfaatan Energi Alternatif Arang Briket dari Sampah Organik bagi Para Fasilitator Lingkungan SeKotamadya Surabaya. Prosiding SENDIMAS 2020 Vol. 5, No. 1 p-ISSN: 2541-559X, eISSN: 2541-3805 hal 325-328.

Purnama, Chumaidi \& Saleh, 2012, Pemanfaatan Limbah Cair CPO Sebagai Perekat pada
Pembuatan Briket dari Arang Tandan Kosong Kelapa Sawit , Jurnal teknik Kimia , 18(3), 4553.

Utami, B. (2015), Pembuatan dan Karakteristik Briket Arang dari Limbah Tempurung Kemiri (Aleurites Moluccana) dengan Menggunakan Variasi Jenis Bahan Perekat dan Jumlah Bahan Perekat, Prosiding Seminar Nasional Kimia 2015, Jurdik Kimia-FMIPA-UNY hal. 59-69, ISBN 978-602-14548-2-4.

Hosiana MD, Labania, Nismayanti, A. 2014, Studi Uji Karakterisitk Fisis Briket Bioarang Sebagai Sumber Energi Aternatif, Online Jurnal of Natural Science, Vol.3(1): 89-98 ISSN: 2338-0950 March 2014

Silvia Septhiani, Eka Septiani, 2015, Peningkatan Mutu Briket dari Sampah Organik dengan Penambahan Minyak Jelantah dan Plastik High Density Polyethylene (HDPE), Jurnal Kimia VALENSI: Jurnal Penelitian dan Pengembangan Ilmu Kimia, 1(2), November 2015, 91-96

https://surabaya.kompas.com/read/2019/07/31/19 543701/anggaran-pengelolaan-sampah-disurabaya-rp-30-miliar-untuk-apasaja?page $=$ all , diakses tanggal 14 Agustus 2019.

Ika Yudhita \&Budi Utami, 2015, Pembuatan dan karakteristik Briket Arang dari Limbah Tempurung Kemiri dengan Menggunakan Variasi Jenis Bahan Perekat dan Jumlah Bahan Perekat, Prosiding Seminar Nasional Kimia 2015, Jurdik Kimia-FMIPA-UNY hal. 59-69, ISBN 978-602-14548-2-4. 